\title{
Accessible surface glycopeptide motifs on Spike glycoprotein of 2019-nCoV: implications
} on vaccination and antibody therapeutics

Dapeng Zhou ${ }^{1 *}$, Ruibing Qi ${ }^{2}$,Wen Zhang ${ }^{3,4}$ *

${ }^{1}$ Tongji University School of Medicine, Shanghai, 200092, China;

${ }^{2}$ Innovation Team of Small Animal ${ }^{2}$ Infectious Disease, Shanghai Veterinary Research Institute, Chinese Academy of Agricultural Science, Shanghai 200241, China

${ }^{3}$ Fudan University Pudong Medical Center, Institutes of Biomedical Sciences; ${ }^{4}$ Department of Systems Biology for Medicine, Shanghai Medical College, Fudan University, 200032, China

*Corresponding authors:

dapengzhoulab@,tongji.edu.cn

wenz@,fudan.edu.cn 


\begin{abstract}
Corona viruses hijack human glycosylation enzymes to assembly sugar coat on Spike glycoproteins to evade antibody neutralization. The mechanism that human antibodies may uncover the antigenic viral peptide epitopes hidden by sugar coat are unknown. In this study, we analyzed the high-resolution Cryo-EM structure of Spike glycoproteins with the focus on calculating the accessible surface and studying the effect of glycosylation. The results showed that electron densities of glycans cover most of the SARS-CoV Spike protein RBD region except FSPDGKPCTPPALNCYWPLNDYGFYTTTGIGYQ. The glycosylated 2019-nCoV Spike protein by homology structure modeling showed a similar exposed sequence in RBD, YQAGSTPCNGVEGFNCYFPLQSYGFQPTNGVGYQ. Other surface-exposed domains included Central Helix, which is located between amino acids 967 and 1016 of SARS-CoV Spike protein, and amino acids 985 to 1034 of 2019-nCoV Spike protein. As the majority of antibody paratopes bind to peptide portion with or without sugar modification, we propose a snake-catcher model that a minimal length of peptide portion is first clamped by a paratope, and the binding is either strengthened by sugars close to peptide portion, or not interfered by sugar modification.
\end{abstract}

Key words: 2019-nCoV; corona virus; glycopeptide; N-linked glycans; antibody; cryo-EM structure; crystal structures; epitope prediction 


\section{Introduction}

Spike proteins are located on the surface of corona viruses and serve as entry proteins for infection (1). The Spike molecule forms trimers, which must be cleaved by cellular proteases so that the fusion peptide can facilitate the fusion of virus membrane with the infected cells. The proteases generate S1 and S2 subunits from Spike molecule, and the S1 subunit contains the critical receptor binding domain (RBD) to bind ACE2 of host cells. The receptor binding motif (RBM) of the receptor binding domain, rich in tyrosine, forms direct contacts with ACE2. The fusion of the virus with the host cells involves several other critical structures of the Spike protein, including Central Helix $(\mathrm{CH})$ and heptad repeat 1 and 2 (HR1 and HR2) domains.

Spike glycoproteins are major targets for vaccine design and antibody-based therapies for corona viruses. Several antibodies targeting Spike proteins of SARS-CoV showed promising efficacy in preclinical trials (2-18). Besides the crucial RBD, structural studies suggest that other domains including fusion peptide, HR1 and Central Helix are also potential targets for antibody binding (19). In all corona viruses, Spike glycoproteins are densely glycosylated, with more than 20 predicted sites for $\mathrm{N}$-glycosylation. The function of these glycans in immune escape of virus remain unknown.

In this study, we analyzed the cryo-EM structure of recombinant SARS-CoV Spike protein expressed by insect (Sf9) cells (19). We further used the homology-modeled structure of glycosylated 2019-CoV Spike protein, to identify surface-exposed epitopes for antibody recognition as well as vaccine design. 


\section{Results}

\section{Predicted N-glycosylation sites for coronal viruses}

A total of $22 \mathrm{~N}$-glycosylation sites were found in Spike protein of 2019-nCoV. Among them 8 are located in N-terminal domain (NTD), 2 are located in receptor-binding domain (RBD), 3 are located in the rest of S1 subunit. 9 are located in the S2 subunit. The glycosylation pattern of Spike protein is highly conserved in SARS, MERS, and 2019-nCoV corona viruses. The NTD and HR2 domains are densely glycosylated. The fusion peptide (FP) domain is closely neighbored by a glycosylation site. In contrast, the receptor binding motif, the $\mathrm{CH}$ domain and the HR1 domain are free of glycosylation (Figure 1 and Supplemental Figure 1).

By Cryo-EM structure modeling (PDB: 5X58), 14 sites of $\mathrm{N}$-glycosylation were observed. The GlcNAc (NAG) groups were identified at the reducing end of glycans, and the density map of extending glycan chains are still visible although the density is relatively weak (Figure 2A, B, and C). The RBD region of SARS-CoV Spike protein is covered by glycan density except FSPDGKPCTPPALNCYWPLNDYGFYTTTGIGYQ, which overlaps with an "Achilles heel” for antibody binding as pointed out by Berry et al (9).

The predicted glycosylation sites for Spike protein of 2019-nCoV include 22 N-glycosylation sites (displayed in yellow in Figure 2D). When trimer structures of S protein of SARS-CoV and 2019$\mathrm{nCoV}$ are aligned (RMSD 1.32 for single chain), the structures are very similar except few loops, such as those at the N-terminal of NTD (Supplemental Figure 2). The predicted glycosylation sites are most conserved by sequence alignment and structure comparison. Fourteen of 22 sites are 
observed by Cryo-EM for SARS-CoV S protein, and most predicted sites of 2019-nCoV are located similarly to SARS-CoV (Figure 2E). The RBD domain are overall highly conserved with sequence identity (74.5\%), structure (RMSD 1.14 $)$, and two identical glycosylation-sites near the $\mathrm{N}$ terminal (Figure $2 \mathrm{~F}$ ), while the sequence specificity of epitopes remains unique in some region (Tables 1\&2). A similar surfaced exposed region, or "Achilles heel", YQAGSTPCNGVEGFNCYFPLQSYGFQPTNGVGYQ, was identified in RBD of 2019-nCoV. Interestingly, the "Achilles heel" for both SARS-CoV and 2019-nCoV is also free of glycosylation, while its neighbor fragments are covered or interacted by glycosylation. This region free of glycosylation is favorable for ACE2 and other protein binding (Figure 2G).

\section{Accessible surface area (ASA) calculated according to electron density of glycans on Spike proteins of SARS-CoV and 2019-nCoV}

The ASA profiling was used for mAb epitopes prediction (Supplemental Figure 3). Candidate epitopes were listed in Table 1 and Figure 3. In addition to RBD domains, multiple potential candidate epitopes from amino acid sequences at FP, HR1 and $\mathrm{CH}$ domains. Figure 4 shows the alignment of epitopes of Spike proteins of SARS-CoV and 2019-nCoV. Similar sites were found in $\mathrm{RBD}$ domains and $\mathrm{CH}$ domains of both viruses. However, unique sites were also found for each virus (Table 2 and Supplemental Figure 4). A unique epitope only existing in 2019-nCoV, but not in SARS-CoV, is the RARR (682-685) site for furin recognition (Supplemental Figure 5).

\section{Discussion}

Neutralizing antibodies toward Spike proteins are critical for protective immunity. Traggiai et al. reported Spike-specific monoclonal antibodies isolated from a patient who recovered from 
SARS-CoV infection, with in vitro neutralizing activity ranging from $10^{-8} \mathrm{M}$ to $10^{-11} \mathrm{M}(2)$. Several other groups reported monoclonal antibodies targeting Spike (3-15). Spike protein has also been the focus for vaccine development (20). High titers of IgG antibodies were reported to protect mice from SARS-CoV or MERS-CoV viral infection in mice vaccinated by DNA or subunit vaccines composed by Spike proteins (or RBD of Spike proteins) and adjuvants (21-29). TLR ligands, delta inulin, monophosphoryl lipid A were reported as effective adjuvants to be combined with subunit vaccines. To avoid the use of adjuvant, inactivated SARS-CoV viruses or recombinant adeno-associated virus encoding $\mathrm{RBD}$ of SARS-CoV spike protein have been studied, which induced potent protective antibody responses against infection (30-33). The safety and efficacy of antibody therapeutics and vaccines in human clinical trials remain to be studied, as well as the mechanism for specific vaccine component and formulation. For example, pulmonary pathology was reported when alum was used as adjuvant for Spike protein subunit vaccine (34). Antibody-induced lung injury was also reported in macaque model of SARS-CoV infection (35), which highlights the importance to avoid antibody-medicated inflammation.

RBD domain has been a main focus for antibody and vaccine studies. Three antibodies complexed with RBD of SARS-CoV has been co-crystalized, including 80R, m396, F26G19 (16-18). All three antibodies recognize non-continuous, conformational epitopes (Supplemental Table 1). Several mAb clones that recognize linear continuous peptide sequences have been reported (4D5, 17H9, F26G18, and 201), although co-crystal structures are not available yet. In this study, we have identified the ASA profiling of RBD of 2019-nCoV, and found a vulnerable region, YQAGSTPCNGVEGFNCYFPLQSYGFQPTNGVGYQ. Previously, the 
structural counterpart of this region is termed as "the Achilles heel" of SARS-CoV (9). It is mostly overlapped with the interface between ACE2 and S protein (Figure 1G). For SARS-CoV, multiple mAbs targeting the "the Achilles heel" of SARS-CoV have been generated, including F26G18, 4D5, CR3006, m396, FM39, CR3014, F26G19 and 80R (Supplemental Table 1). Ongoing studies are being focused on the epitopes at "the Achilles heel" of 2019-nCoV for antibody and vaccine development.

In the past, it is well known that the predicted epitopes of protein antigens may be masked by glycosylation. Complex dataset and algorithm have been developed, which are based on training parameters related to interactions of glycans and surrounding amino acids, such as SEPPA 3.0 (36). However, no experimental data is available on the effect of glycosylation sites on epitope surface. With the recent breakthrough by high-resolution Cryo-EM, many glycoproteins can be solved and modeled with glycosylation sites. Here we directly exploit experiment data of SARSCoV Spike protein from high resolution Cryo-EM, and screened epitopes for 2019-nCoV Spike protein by ASA profiling based on homology-modeled structure. By this approach, we have identified the "Achilles heel" of 2019-nCoV virus, as well as multiple other surface-exposed epitopes within and outside of RBD. For example, in NBD domain of SARS-CoV Spike protein, mAbs specific for linear epitopes have been reported (3, Supplemental Table 1). MAbs specific to other regions of S1 subunit and S2 subunits of SARS-CoV Spike protein were also reported (6). As summarized in Table 1, promising antibody binding sites within RBD and outside of RBD have been identified for 2019-nCoV, future studies will be focused on vaccination studies to validate their function as neutralizing epitopes with preventive and therapeutic effects in virus challenge experiments. 
Dense glycosylation of glycoproteins is a well-known strategy used by viruses to conceal surface peptide epitopes which elicit antibody responses, as exemplified by Env protein of HIV-1 virus. However, after decades of effort, monoclonal antibodies which bind to conformational epitopes on surface of the Env protein have been identified (36-38). Most of these antibodies bind to Nglycan portion neighboring the peptide epitopes, while some antibodies such as mAb 8ANC195 have evolved to recognize peptide epitope with no dependence on glycan binding (36). For antibodies specific to Spike glycoproteins, there is no data available whether their recognition is interfered by the glycosylation of Spike. We propose a "snake catcher" model that a minimum length of peptide portion, either linear continuous, or conformational, must first be first clamped by a paratope. This clamping effect may either be strengthened by sugars close to the peptide epitope, or not interfered by sugar modification. Clearly, the availability of surface-exposed glycopeptide motifs are critical for inducing antibody responses.

In summary, our study clearly identified list of linear surface exposed epitopes in Spike proteins of SARS-CoV and 2019-nCoV, and demonstrated the advantages to study glycosylation effect with real Cryo-EM data. These epitopes are critical for screening of monoclonal antibody therapeutics to treat 2019-nCoV viruses, as well as mechanistic studies on vaccine development.

\section{Methods}

\section{Prediction of glycosylation sites}

Spike proteins for 2019-nCoV (GenBank Accession Number: MN908947), SARS-CoV

(AB263618), MERS (KM027290) were predicted by NetNGlyc. 
The sequence identity of the spike proteins between 2019-nCoV and SARS-CoV is as high as $84 \%$, which is sufficient to build an accurate homolog model. The sequence of MN908947 was submitted and the structure model was built against all available homolog structures as templates by SWISS-MODEL (https://swissmodel.expasy.org). One stable conformation of trimer structure models for 2019-nCov is very close to Spike protein structure from SARS-CoV (PDB: 5X58), and their RMSD of single protein chain is about $1.32 \AA$ after two structures are superimposed and compared in PyMol (Figure 2D\&E).

\section{Calculation according to electron density of glycans on SARS-CoV Spike protein}

Glycosylation sites were solved and determined from high-resolution Cryo-EM density map, while only N-Acetyl-D-glucosamine (NAG, GlcNAc) is determined to represent a whole glycan due to the glycan flexibility and disorder. The SARS spike protein structure (PDB:5X58), together with the NAG (GlcNAc) sites, were applied for molecular interface calculation with PISA (http://www.ccp4.ac.uk/pisa/). All the amino acids linking or interacting with NAG (GlcNAc) were selected and excluded in epitope prediction. Besides the interaction between NAG (GlcNAc at reducing end) and amino acids, the effects of larger structure of glycans extending from every NAG (GlcNAc) may also need to be considered, as shown as in Figure 2C, although their electron densities are weak.

\section{Calculation according to homology-modeled structure of 2019-CoV protein}

The same molecular interface calculation procedure described above was applied to calculate the ASA and screen the corresponding antigen epitopes, except the glycosylation effect could not be measured due to structure unavailable so far. As most glycosylation sites are conserved due to 
high similarity of these two spike proteins, we could predict the glycosylation site effects in 2019-nCoV spike structure as well. When predicted epitopes collide with the amino acid residues interacting with NAG (GlcNAc), they were removed from the candidates by cross-reference of the SARS-CoV data.

\section{Acknowledgement}

This work was supported by National Natural Science Foundation of China grant 31870972 (DZ) and 11179012 (WZ), National Key Research and Development Plan grant 2017YFA0505901, and Fundamental Research Funds for the Central Universities 22120180201. All these sponsors have no roles in the study design, or the collection, analysis, and interpretation of data.

\section{Conflict of interest disclosures}

The authors declare no conflict of interest.

\section{Author contributions}

Dapeng Zhou and Wen Zhang designed this study. Dapeng Zhou, Ruibing Qi and Wen Zhang contributed to the collection, analysis and interpretation of data. Dapeng Zhou and Wen Zhang wrote the manuscript. All authors read and approved the final manuscript.

\section{Reference:}

1. Xu, Y. et al. Crystal structure of severe acute respiratory syndrome coronavirus spike protein fusion core. J. Biol. Chem. 279, 49414-49419 (2004). 
2. Traggiai E, Becker S, Subbarao K, Kolesnikova L, Uematsu Y, Gismondo MR, Murphy BR, Rappuoli R, Lanzavecchia A. An efficient method to make human monoclonal antibodies from memory B cells: potent neutralization of SARS coronavirus. Nat Med. 2004 Aug;10(8):871-5.

3. Greenough TC, Babcock GJ, Roberts A, Hernandez HJ, Thomas WD Jr, Coccia JA, Graziano RF, Srinivasan M, Lowy I, Finberg RW, Subbarao K, Vogel L, Somasundaran M, Luzuriaga K, Sullivan JL, Ambrosino DM. Development and characterization of a severe acute respiratory syndrome-associated coronavirus-neutralizing human monoclonal antibody that provides effective immunoprophylaxis in mice. J Infect Dis. 2005 Feb 15;191(4):507-14.

4. Sui J, Li W, Roberts A, Matthews LJ, Murakami A, Vogel L, Wong SK, Subbarao K, Farzan M, Marasco WA. Evaluation of human monoclonal antibody 80R for immunoprophylaxis of severe acute respiratory syndrome by an animal study, epitope mapping, and analysis of spike variants. J Virol. 2005 May;79(10):5900-6.

5. Ishii K, Hasegawa H, Nagata N, Ami Y, Fukushi S, Taguchi F, Tsunetsugu-Yokota Y. Neutralizing antibody against severe acute respiratory syndrome (SARS)-coronavirus spike is highly effective for the protection of mice in the murine SARS model. Microbiol Immunol. 2009 Feb;53(2):75-82.

6. Miyoshi-Akiyama T, Ishida I, Fukushi M, Yamaguchi K, Matsuoka Y, Ishihara T, Tsukahara M, Hatakeyama S, Itoh N, Morisawa A, Yoshinaka Y, Yamamoto N, Lianfeng Z, Chuan Q, Kirikae T, Sasazuki T. Fully human monoclonal antibody directed to proteolytic cleavage site in severe acute respiratory syndrome (SARS) coronavirus S protein neutralizes the virus in a rhesus macaque SARS model. J Infect Dis. 2011 Jun 1;203(11):1574-81.

7. Bian C, Zhang X, Cai X, Zhang L, Chen Z, Zha Y, Xu Y, Xu K, Lu W, Yan L, Yuan J, Feng J, Hao P, Wang Q, Zhao G, Liu G, Zhu X, Shen H, Zheng B, Shen B, Sun B. Conserved amino acids W423 and N424 in receptor-binding domain of SARS-CoV are potential targets for therapeutic monoclonal antibody. Virology. 2009 Jan 5;383(1):39-46.

8. He Y, Lu H, Siddiqui P, Zhou Y, Jiang S. Receptor-binding domain of severe acute respiratory syndrome coronavirus spike protein contains multiple conformation-dependent epitopes that induce highly potent neutralizing antibodies. J Immunol. 2005 Apr 15;174(8):4908-15. 
9. Berry JD, Hay K, Rini JM, Yu M, Wang L, Plummer FA, Corbett CR, Andonov A. Neutralizing epitopes of the SARS-CoV S-protein cluster independent of repertoire, antigen structure or mAb technology. MAbs. 2010 Jan-Feb;2(1):53-66. Epub 2010 Jan 27.

10. van den Brink EN, Ter Meulen J, Cox F, Jongeneelen MA, Thijsse A, Throsby M, Marissen WE, Rood PM, Bakker AB, Gelderblom HR, Martina BE, Osterhaus AD, Preiser W, Doerr HW, de Kruif J, Goudsmit J. Molecular and biological characterization of human monoclonal antibodies binding to the spike and nucleocapsid proteins of severe acute respiratory syndrome coronavirus. J Virol. 2005 Feb;79(3):1635-44.

11. Zhu Z, Chakraborti S, He Y, Roberts A, Sheahan T, Xiao X, Hensley LE, Prabakaran P, Rockx B, Sidorov IA, Corti D, Vogel L, Feng Y, Kim JO, Wang LF, Baric R, Lanzavecchia A, Curtis KM, Nabel GJ, Subbarao K, Jiang S, Dimitrov DS. Potent cross-reactive neutralization of SARS coronavirus isolates by human monoclonal antibodies. Proc Natl Acad Sci U S A. 2007 Jul 17;104(29):12123-8.

12. Sui J, Deming M, Rockx B, Liddington RC, Zhu QK, Baric RS, Marasco WA. Effects of human antispike protein receptor binding domain antibodies on severe acute respiratory syndrome coronavirus neutralization escape and fitness. J Virol. 2014 Dec;88(23):13769-80.

13. ter Meulen J, van den Brink EN, Poon LL, Marissen WE, Leung CS, Cox F, Cheung CY, Bakker AQ, Bogaards JA, van Deventer E, Preiser W, Doerr HW, Chow VT, de Kruif J, Peiris JS, Goudsmit J. Human monoclonal antibody combination against SARS coronavirus: synergy and coverage of escape mutants. PLoS Med. 2006 Jul;3(7):e237.

14. He Y, Li J, Heck S, Lustigman S, Jiang S. Antigenic and immunogenic characterization of recombinant baculovirus-expressed severe acute respiratory syndrome coronavirus spike protein: implication for vaccine design. J Virol. 2006 Jun;80(12):5757-67.

15. Rockx B, Corti D, Donaldson E, Sheahan T, Stadler K, Lanzavecchia A, Baric R. Structural basis for potent cross-neutralizing human monoclonal antibody protection against lethal human and zoonotic severe acute respiratory syndrome coronavirus challenge. J Virol. 2008 Apr;82(7):3220-35.

16. Pak JE, Sharon C, Satkunarajah M, Auperin TC, Cameron CM, Kelvin DJ, Seetharaman J, Cochrane A, Plummer FA, Berry JD, Rini JM. Structural insights into immune recognition of the severe acute respiratory syndrome coronavirus S protein receptor binding domain. J Mol Biol. 2009 May 15;388(4):815-23. 
17. Prabakaran P, Gan J, Feng Y, Zhu Z, Choudhry V, Xiao X, Ji X, Dimitrov DS. Structure of severe acute respiratory syndrome coronavirus receptor-binding domain complexed with neutralizing antibody. J Biol Chem. 2006 Jun 9;281(23):15829-36.

18. Hwang WC, Lin Y, Santelli E, Sui J, Jaroszewski L, Stec B, Farzan M, Marasco WA, Liddington RC. Structural basis of neutralization by a human anti-severe acute respiratory syndrome spike protein antibody, 80R. J Biol Chem. 2006 Nov 10;281(45):34610-6.

19. Yuan Y, Cao D, Zhang Y, Ma J, Qi J, Wang Q, Lu G, Wu Y, Yan J, Shi Y, Zhang X, Gao GF. CryoEM structures of MERS-CoV and SARS-CoV spike glycoproteins reveal the dynamic receptor binding domains. Nat Commun. 2017 Apr 10;8:15092.

20. He Y, Zhou Y, Wu H, Luo B, Chen J, Li W, Jiang S. Identification of immunodominant sites on the spike protein of severe acute respiratory syndrome (SARS) coronavirus: implication for developing SARS diagnostics and vaccines. J Immunol. 2004 Sep 15;173(6):4050-7.

21. Yang ZY, Kong WP, Huang Y, Roberts A, Murphy BR, Subbarao K, Nabel GJ. A DNA vaccine induces SARS coronavirus neutralization and protective immunity in mice. Nature. 2004 Apr 1;428(6982):561-4.

22. Du L, Zhao G, He Y, Guo Y, Zheng BJ, Jiang S, Zhou Y. Receptor-binding domain of SARS-CoV spike protein induces long-term protective immunity in an animal model. Vaccine. 2007 Apr 12;25(15):28328.

23. Lu B, Huang Y, Huang L, Li B, Zheng Z, Chen Z, Chen J, Hu Q, Wang H. Effect of mucosal and systemic immunization with virus-like particles of severe acute respiratory syndrome coronavirus in mice. Immunology. 2010 Jun;130(2):254-61.

24. Du L, Zhao G, Chan CC, Li L, He Y, Zhou Y, Zheng BJ, Jiang S. A 219-mer CHO-expressing receptor-binding domain of SARS-CoV S protein induces potent immune responses and protective immunity. Viral Immunol. 2010 Apr;23(2):211-9.

25. Li J, Ulitzky L, Silberstein E, Taylor DR, Viscidi R. Immunogenicity and protection efficacy of monomeric and trimeric recombinant SARS coronavirus spike protein subunit vaccine candidates. Viral Immunol. 2013 Apr;26(2):126-32. 
26. Zhao J, Li K, Wohlford-Lenane C, Agnihothram SS, Fett C, Zhao J, Gale MJ Jr, Baric RS, Enjuanes L, Gallagher T, McCray PB Jr, Perlman S. Rapid generation of a mouse model for Middle East respiratory syndrome. Proc Natl Acad Sci U S A. 2014 Apr 1;111(13):4970-5.

27. Iwata-Yoshikawa N, Uda A, Suzuki T, Tsunetsugu-Yokota Y, Sato Y, Morikawa S, Tashiro M, Sata T, Hasegawa H, Nagata N. Effects of Toll-like receptor stimulation on eosinophilic infiltration in lungs of $\mathrm{BALB} / \mathrm{c}$ mice immunized with UV-inactivated severe acute respiratory syndrome-related coronavirus vaccine. J Virol. 2014 Aug;88(15):8597-614.

28. Honda-Okubo Y, Barnard D, Ong CH, Peng BH, Tseng CT, Petrovsky N. Severe acute respiratory syndrome-associated coronavirus vaccines formulated with delta inulin adjuvants provide enhanced protection while ameliorating lung eosinophilic immunopathology. J Virol. 2015 Mar;89(6):2995-3007.

29. Sekimukai H, Iwata-Yoshikawa N, Fukushi S, Tani H, Kataoka M, Suzuki T, Hasegawa H, Niikura K, Arai K, Nagata N. Gold nanoparticle-adjuvanted S protein induces a strong antigen-specific IgG response against severe acute respiratory syndrome-related coronavirus infection, but fails to induce protective antibodies and limit eosinophilic infiltration in lungs. Microbiol Immunol. 2020 Jan;64(1):33-51.

30. Du L, Zhao G, Lin Y, Sui H, Chan C, Ma S, He Y, Jiang S, Wu C, Yuen KY, Jin DY, Zhou Y, Zheng BJ. Intranasal vaccination of recombinant adeno-associated virus encoding receptor-binding domain of severe acute respiratory syndrome coronavirus (SARS-CoV) spike protein induces strong mucosal immune responses and provides long-term protection against SARS-CoV infection. J Immunol. 2008 Jan 15;180(2):948-56.

31. See RH, Zakhartchouk AN, Petric M, Lawrence DJ, Mok CP, Hogan RJ, Rowe T, Zitzow LA, Karunakaran KP, Hitt MM, Graham FL, Prevec L, Mahony JB, Sharon C, Auperin TC, Rini JM, Tingle AJ, Scheifele DW, Skowronski DM, Patrick DM, Voss TG, Babiuk LA, Gauldie J, Roper RL, Brunham RC, Finlay BB. Comparative evaluation of two severe acute respiratory syndrome (SARS) vaccine candidates in mice challenged with SARS coronavirus. J Gen Virol. 2006 Mar;87(Pt 3):641-50.

32. Spruth M, Kistner O, Savidis-Dacho H, Hitter E, Crowe B, Gerencer M, Brühl P, Grillberger L, Reiter M, Tauer C, Mundt W, Barrett PN. A double-inactivated whole virus candidate SARS coronavirus vaccine stimulates neutralising and protective antibody responses. Vaccine. 2006 Jan 30;24(5):652-61. 
33. Okada M, Takemoto Y, Okuno Y, Hashimoto S, Yoshida S, Fukunaga Y, Tanaka T, Kita Y, Kuwayama S, Muraki Y, Kanamaru N, Takai H, Okada C, Sakaguchi Y, Furukawa I, Yamada K, Matsumoto M, Kase T, Demello DE, Peiris JS, Chen PJ, Yamamoto N, Yoshinaka Y, Nomura T, Ishida I, Morikawa S, Tashiro M, Sakatani M. The development of vaccines against SARS corona virus in mice and SCID-PBL/hu mice. Vaccine. 2005 Mar 18;23(17-18):2269-72.

34. Tseng CT, Sbrana E, Iwata-Yoshikawa N, Newman PC, Garron T, Atmar RL, Peters CJ, Couch RB. Immunization with SARS coronavirus vaccines leads to pulmonary immunopathology on challenge with the SARS virus. PLoS One. 2012;7(4):e35421.

35. Liu L, Wei Q, Lin Q, Fang J, Wang H, Kwok H, Tang H, Nishiura K, Peng J, Tan Z, Wu T, Cheung KW, Chan KH, Alvarez X, Qin C, Lackner A, Perlman S, Yuen KY, Chen Z. Anti-spike IgG causes severe acute lung injury by skewing macrophage responses during acute SARS-CoV infection. JCI Insight. 2019 Feb 21;4(4). . pii: 123158.

36. Kong L, Torrents de la Peña A, Deller MC, Garces F, Sliepen K, Hua Y, Stanfield RL, Sanders RW, Wilson IA. Complete epitopes for vaccine design derived from a crystal structure of the broadly neutralizing antibodies PGT128 and 8ANC195 in complex with an HIV-1 Env trimer. Acta Crystallogr D Biol Crystallogr. 2015 Oct; 71(Pt 10):2099-108.

37. Kong L, Lee JH, Doores KJ, Murin CD, Julien JP, McBride R, Liu Y, Marozsan A, Cupo A, Klasse PJ, Hoffenberg S, Caulfield M, King CR, Hua Y, Le KM, Khayat R, Deller MC, Clayton T, Tien H, Feizi T, Sanders RW, Paulson JC, Moore JP, Stanfield RL, Burton DR, Ward AB, Wilson IA. Supersite of immune vulnerability on the glycosylated face of HIV-1 envelope glycoprotein gp120. Nat Struct Mol Biol. 2013 Jul;20(7):796-803.

38. Garces F, Lee JH, de Val N, de la Pena AT, Kong L, Puchades C, Hua Y, Stanfield RL, Burton DR, Moore JP, Sanders RW, Ward AB, Wilson IA. Affinity Maturation of a Potent Family of HIV Antibodies Is Primarily Focused on Accommodating or Avoiding Glycans. Immunity. 2015 Dec 15;43(6):1053-63. 


\section{Figure legends:}

Figure 1. N-glycosylation sites of 2019-CoV. NTD, N-terminal domain; RBD, receptor binding domain; FP, fusion peptide; HR1, helix region 1; $\mathrm{CH}$, central helix; HR2, helix region 2.

\section{Figure 2. The spike structures of SARS and 2019-nCoV}

A. The SARS-CoV spike protein structure (green, PDB:5X58) and its density map (yellow) with glycosylation (pink) from the solvent side view;

B. Bottom view with surface area of RBD (the "Achilles Heel", AH, blue) exposed in solvent; C. The typical NAG and its density map, indicated with arrows, extending to outside solvent or neighbor amino acids;

D. The 2019-nCoV spike protein structure (cyan) with glycosylation amino acids (yellow) and RBD highlighted;

E. Structure comparison between The SARS-CoV (middle) and 2019-nCoV protein;

F. The comparison of RBD domains ( dash line circled on 2019-nCoV S protein) between SARS-CoV S protein (RBD: Orange) and 2019-nCoV protein( RBD: deep blue) with AH surface map (blue); notes: the glycosylation sites from SARS-CoV and 2019-nCov S protein are surrounding the RBD domain;

G. AH fragment (sphere) of RBD domain (orange) in closeup view ( dash line circled part); The interface (blue) between SARS -CoV S protein (wheat) and ACE2 (yellow) from the complex structure (PDB:6ACJ);notes: the interface is exactly located on the AH fragment of the complex structure (4.2 angstroms Cryo-EM structure). 
Figure 3. Surface-exposed amino acid sequences predicted by ASA profiling and glycosylation effect with Cryo-EM structure. Furin site (Red pentagram), N-glycosylation sites (*); epitopes for SARS-CoV (green) and 2019-nCoV (cyan).

Figure 4. Alignment of epitopes on the spike protein structure of SRAS and 2019-nCoV.

A. The comparison of the protein chain A between SARS-CoV trimer (in green, chain A specifically in sky blue) and 2019-nCov trimer (cyan), with glycosylation sites (pink at chain A, light pink from other Chains) and their interacting amino acids (yellow) for Chain A of SARS$\mathrm{CoV}$;

B. Four epitope pairs S1/n1, S2/n2, S3/n3, and S4/n4 compared between SARS-CoV (epitopes in red) and 2019-nCov S protein (epitopes in grey or light blue for site n3 ), and 2019-nCov S protein cartoon shown individually on right panel; the conserved fragments at FP (red), HR1 (yellow) and $\mathrm{CH}$ (orange) shown by small cartoon of SARS-CoV trimer (grey) in the middle. The epitopes pairs are listed in the Table 2.

C. Bottom solvent view of the RBD domain located at one side of trimer structure bottom; D. Comparison of epitopes in RBD domains from SARS-CoV (epitopes in red) and 2019-nCov trimer (epitopes in light blue, RBD cartoon in cyan), together shown with AH (dark blue for whole $\mathrm{AH}$, partially overlapping with $\mathrm{AH} /$ ah for epitopes predicted), glycosylation sites (pink) and their interacting amino acids (yellow).

E. The epitopes pairs I/i IV/iv, AH/ah and g1/g2 are compared and listed in the Table 2. 
Table 1. Surface exposed amino acid sequences of SARS-CoV and 2019-nCoV

\begin{tabular}{|c|c|c|c|c|c|}
\hline Sites & 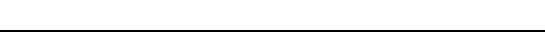 & Epitope details & Nearby N-glycosite & Mab clone & Ref \\
\hline \multicolumn{6}{|c|}{ 2019-nCoV } \\
\hline L18-29 & 18 LTTRTQLPPAYT 29 & & $17 \mathrm{NLT}$ & & \\
\hline G72-75 & 72 GTNG 75 & & 74NGT & & \\
\hline L110-13 & 110 LDSK 113 & & $122 \mathrm{NAT}$ & & \\
\hline Y144-48 & 144 YYHKN 148 & & 149NKS & & \\
\hline W152-58 & 152 WMESEFR 158 & & 149NKS & & \\
\hline A163-66 & 163 ANNC 166 & & $165 \mathrm{NCT}$ & & \\
\hline E169-77 & 169 EYVSQPFLM 177 & & & & \\
\hline G181-84 & 181 GKQG 184 & & & & \\
\hline K206-15 & 206 KHTPINLVRD 215 & & & & \\
\hline R246-56 & 246 RSYLTPGDSSS 256 & & 234NIT & & \\
\hline L270-74 & 270 LQPRT 274 & & 282NGT & & \\
\hline L303-06 & 303 LKSF 306 & & & & \\
\hline P330-36 & 330 PNITNLC 336 & RBD & $331 \mathrm{NIT}$ & & \\
\hline A344-47 & 344 ATRF 347 & RBD & 343NAT & & \\
\hline P384-87 & 384 PTKL 387 & RBD & & & \\
\hline G413-16 & 413 GQTG 416 & RBD & & & \\
\hline S443-51 & 443 SKVG 446,448 NYNY 451 & RBD & & 4D5 & 8 \\
\hline L455-463 & 455 LFRKSNLKP 463 & RBD & & & \\
\hline G476-490 & 476 GSTPC 480,482 GVEGFNCYF 490 & RBD & & & \\
\hline Q498-506 & 498 QPTNGVGYQ 506 & RBD & & 201 & 3 \\
\hline L518-21 & 518 LHAP 521 & RBD & & & \\
\hline P527-33 & 527 PKKSTNL 533 & & & & \\
\hline S555-62 & 555 SNKKFLPF 562 & & & & \\
\hline Q580-83 & 580 QTLE 583 & & & & \\
\hline N603-07 & 603 NTSNQ 607 & & 603NTS,616NCT & & \\
\hline W633-36 & 633 WRVY 636 & & $657 \mathrm{NNS}$ & & \\
\hline E654-62 & 654 EHVNNSYEC 662 & & & & \\
\hline Y674-87 & 674 YQTQTNSPRRARSV 687 & & & & \\
\hline Y707-71 & 707 YSNN 710 & & 709NNS & & \\
\hline S746-51 & 746 STECSN 751 & & & & \\
\hline D808-14 & 808 DPSKPSK 814 & & $801 \mathrm{NFS}$ & $5 \mathrm{H} 10$ & 6 \\
\hline T827-83 & 827 TLAD 830 & & & & \\
\hline I834-54 & 834 IKQYG 838,840 CLGDIAARDLICAQK 854 & $\mathrm{CR}$ & & & \\
\hline T866-69 & 866 TDEM 869 & $\mathrm{CR}$ & & & \\
\hline Q920-23 & 920 QKLI 923 & HR1 & & & \\
\hline D936-44 & 936 DSLSSTASA 944 & HR1 & & & \\
\hline K986-91 & 986 KVEAEV 991 & $\mathrm{CH}$ & & & \\
\hline A1070-76 & 1070 AQEKNFT 1076 & & $1074 \mathrm{NFT}$ & & \\
\hline T1100-03 & 1100 THWF 1103 & & 1098NGT & & \\
\hline Q1113-18 & 1113 QIITTD 1118 & & & & \\
\hline C1126-29 & 1126 CDVV 1129 & & $1134 \mathrm{NNT}$ & & \\
\hline V1133-37 & 1133 VNNTV 1137 & & 1134NNT & & \\
\hline \multicolumn{6}{|c|}{ SARS-CoV } \\
\hline R18-31 & 18 RCTTFDDVQAPNYT 31 & & $29 \mathrm{NYT}$ & & \\
\hline K142-15 & 142 KPMG 145,146 QTHT 150 & & $158 \mathrm{NCT}$ & 68 & 3 \\
\hline S165-17 & 165 SDAFSL 170 & & $158 \mathrm{NCT}$ & & \\
\hline E174-77 & 174 EKSG 177 & & & & \\
\hline V205-08 & 205 VVRD 208 & & & & \\
\hline L257-26 & 257 LKPT 260 & & 269NGT & & \\
\hline $\mathrm{I} 319-23$ & 319 ITNLC 323 & RBD & $318 \mathrm{NIT}$ & & \\
\hline A331-34 & 331 ATKF 334 & RBD & 330NAT & & \\
\hline R342-47 & 342 RKKISN 347 & RBD & $357 \mathrm{NST}$ & & \\
\hline T425-28 & 425 TRNI 428 & RBD & & & \\
\hline $\mathrm{P} 462-76$ & 462 PDGKPCTPPALNCYW 476 & RBD & & 17H9, F26G18,80R & 8,18 \\
\hline Y484-92 & 484 YTTTGIGYQ 492 & RBD & & F26G19, m396, 80R,201 & $3,16,17,18$ \\
\hline $\begin{array}{l}\text { P513-22 } \\
\end{array}$ & 513 PKLSTDLIKN 522 & & & & \\
\hline N589-94 & 589 NASSEV 594 & & 589NAS & & \\
\hline I610-14 & 610 IHADQ 614 & & $602 \mathrm{NCT}$ & F26G8 & 9 \\
\hline Y622-27 & 622 YSTGNN 627 & & & & \\
\hline E640-48 & 640 EHVDTSYEC 648 & & & & \\
\hline H661-73 & $661 \mathrm{HT} 662,672 \mathrm{KS} 673$ & & & & \\
\hline P789-97 & 789 PDPLKPTKR 797 & & 783NFS & $5 \mathrm{H} 10$ & 6 \\
\hline Q917-26 & 917 QESLTTTSTA 926 & HR1 & & & \\
\hline N935-39 & 935 NQNAQ 939 & HR1 & & & \\
\hline K968-73 & 968 KVEAEV 973 & $\mathrm{CH}$ & & & \\
\hline C1064-69 & 1064 CHEGKA 1069 & & $1056 \mathrm{NFT}$ & & \\
\hline G1081-84 & 1081 GTSW 1084 & & $1080 \mathrm{NGT}$ & & \\
\hline Q1095-00 & 1095 QIITTD 1100 & & & & \\
\hline
\end{tabular}




\section{Zhou et al., Figure 1}
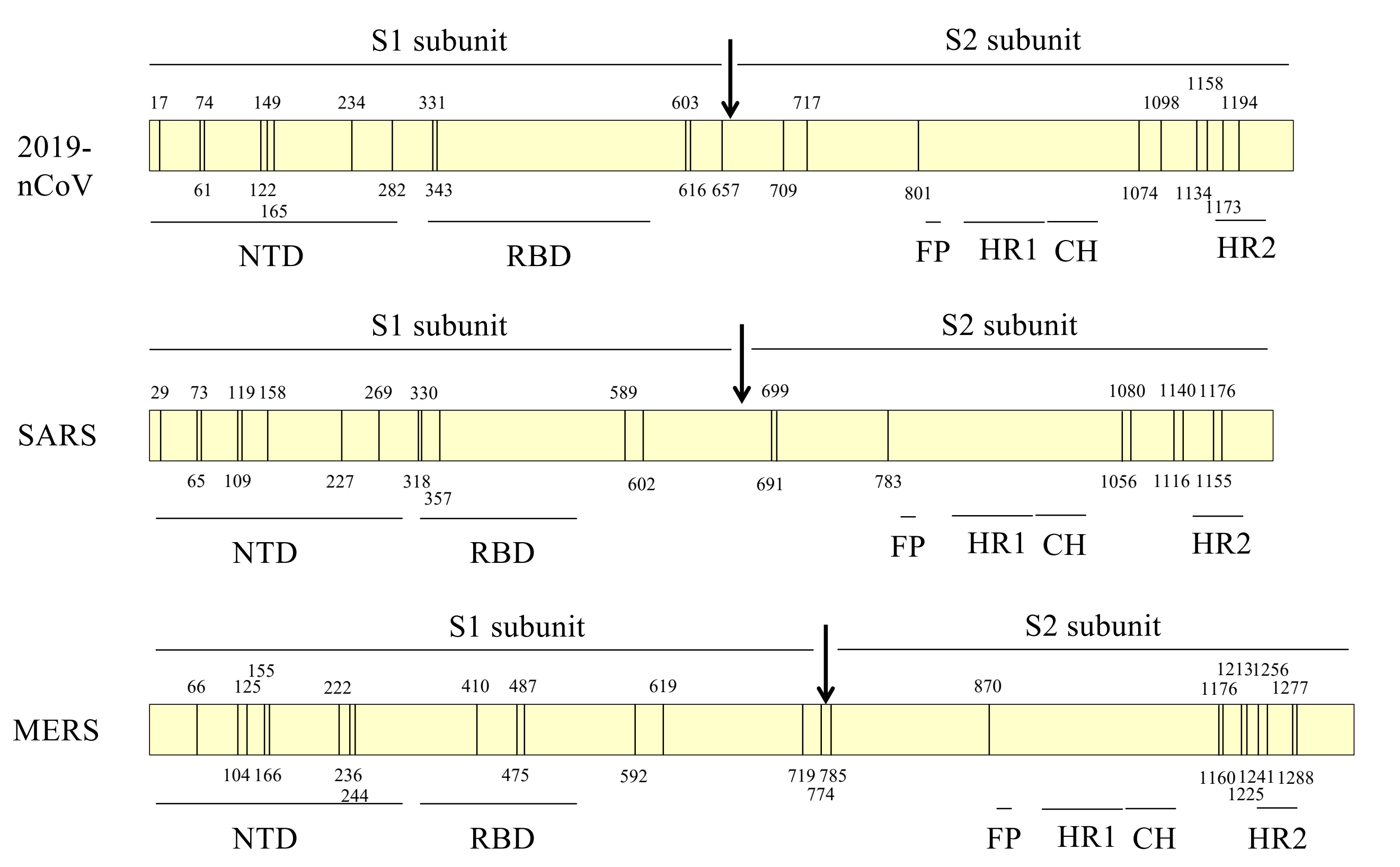


\section{Zhou et al., Figure 2}

\section{$\mathrm{A}|\mathrm{B}| \mathrm{C}$}
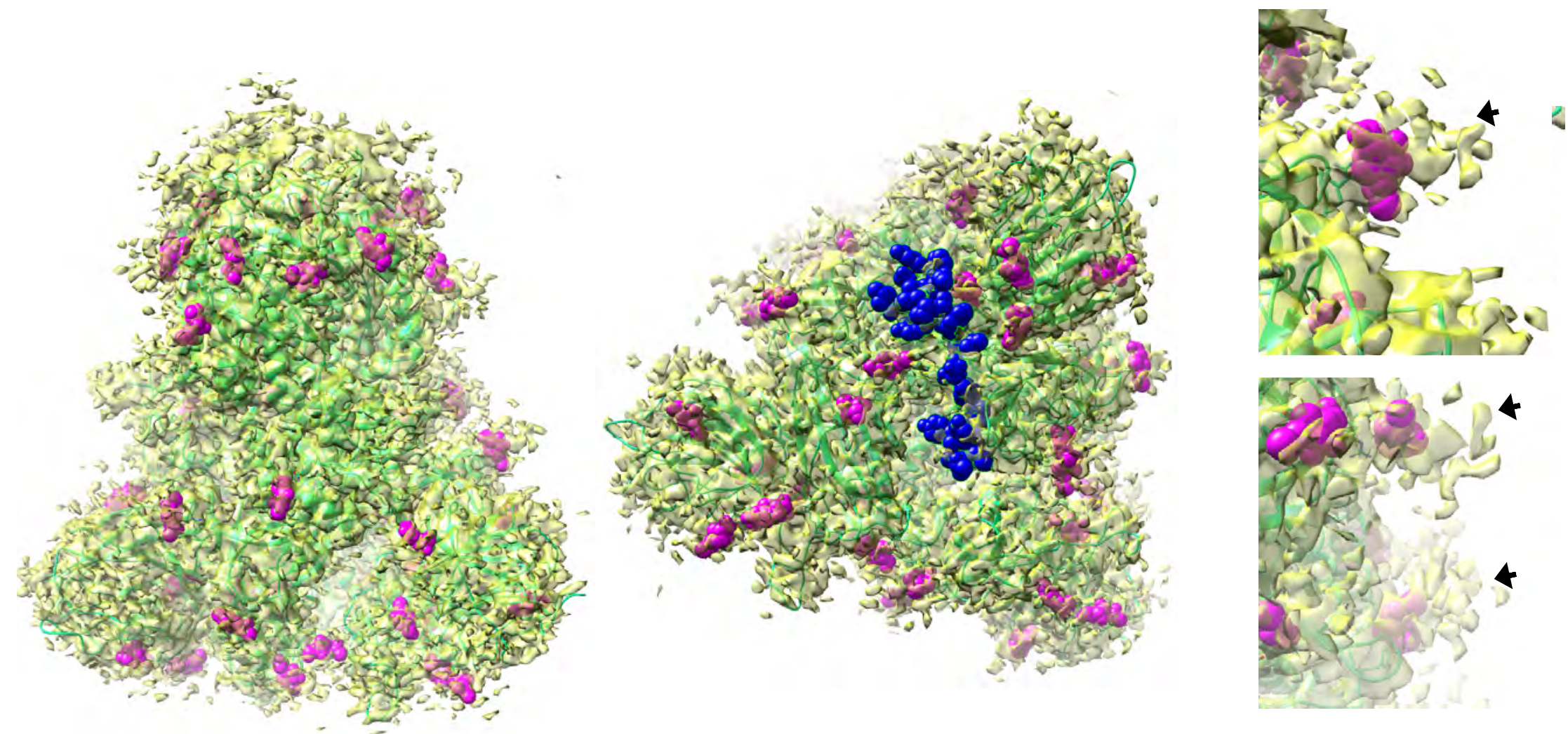


\section{Zhou et al., Figure 2}

\section{$D \mid E$}

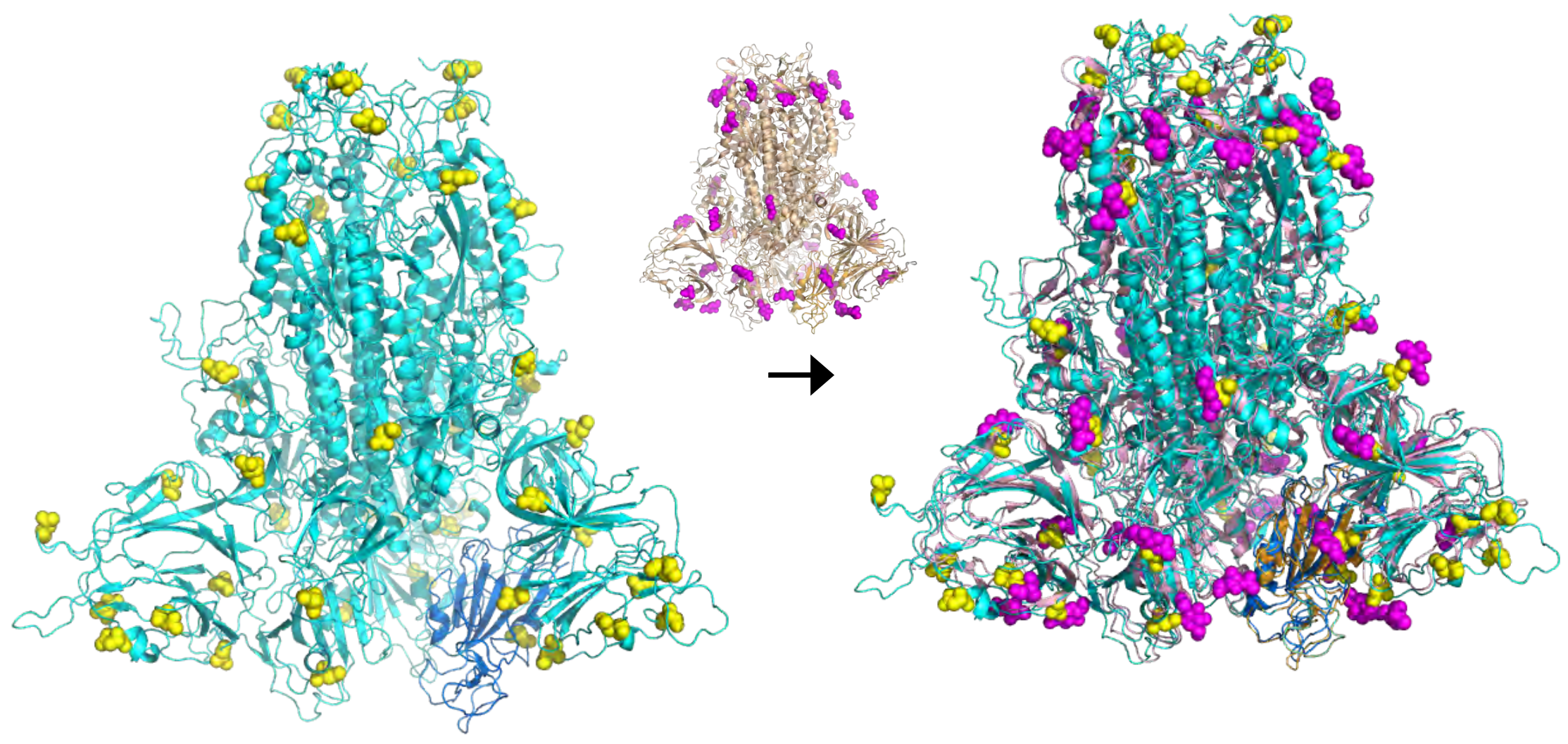




\section{Zhou et al., Figure 2}

\section{$\mathbf{F} \mid \mathbf{G}$}
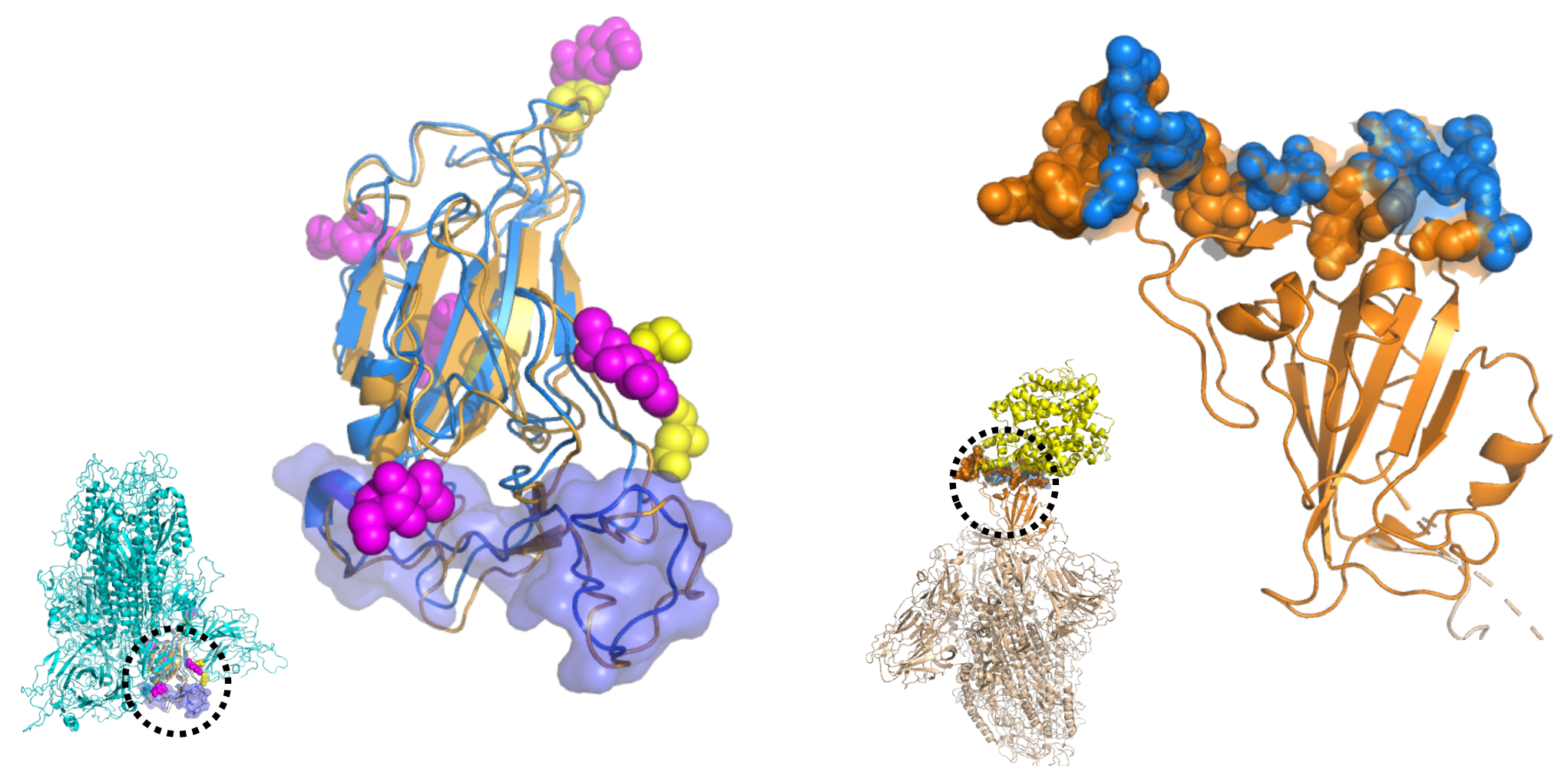


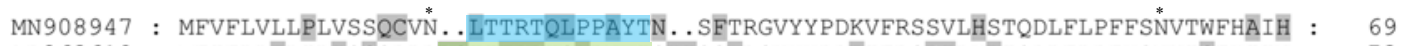
AB263618: MFIFLLFLTLTSGSDLDRCTTFDDVQAPNYTQHTSSMRGVYYPDËIFRSDTLYLTQDLFLPFYSNVTGFHTIN ${ }_{*}^{*} \quad 73$

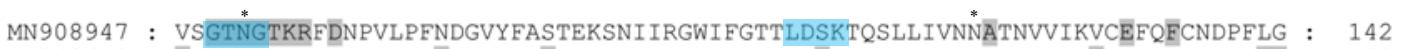
AB263618: $\mathrm{HT}$........FGNPVIPFKDGIYFAÄTEKSNVVRGWVFGSTMNNKSQSVII INNSTNVVIRÄCNFELCDNPFFA : 139

MN908947 : VYYHKNNKSWMESEFRVYSSANNCTFEYVSQPFLMDLEGKQ̄GNFKNLREFVFKNIDGYFKIYSKHTPINLVRD : 215 AB263618 : VSKPMG....TQTHTMIFDNAFNCTFEYISDAFSLDVSEKSGNFKḦLREFVFKNKDGFLYVYKGYQPIDVVRD : 208

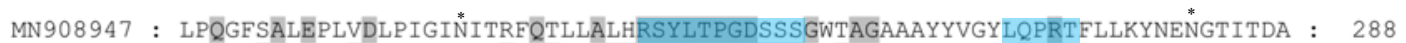
AB263618 : LPSGFNTLKPIFKLPLGINITNNFRAILTAFS.......PAQDIWGTSAAAYFVGYLKPTTFMLKYDENGTITDA : 275

MN908947 : VDCALDPLSETKCTLKSFTVEKGIYQTSNFRVQ̄PTËSIVRFPNITNLCPFGEVFNATREAASVYAWNRKRISNC : 361 AB263618: VDCSQNPLAELKCSVKSFEIDKGIYQTSNFRVVP SDVVRF PNITNLCPFGEVFNATKFPSVYAWERKKISNC : ${ }_{*}^{*}$

\section{RBD}

MN908947 : VADYSVLYNSĀSFSTFKCYGVSPTKLNDLCFTNVYADSFVIRGDEVRQIAPGQTGKIADYNYKLPDDFTGCVI : 434 AB263618 : VADYSVLYNSTFFFSTFKCYGVSẠTKLNDLCF SNVYADSFVVKGDDVRQIAPGQTGVIADYNYKLPDDFMGCVL : 421

MN908947 : AWNSNNLDSKVGGNYNYLYRLFRKSNLKPFERDISTEIYQAGSTPCNGVEGFNCYFPLQSYGFQRTNGVGYQP : 507 AB263618 : AWNTRNIDATSTGNYNYKYRYLRHGKLRPFERDISNVPFSPDGKPCT. PPALNCYWPLNDYGFYTTTGIGYQP: 493

MN908947 : YRVVVLSFELLHAPATVCGPKKSTNLVKNKCVNFNFNGLTGTGVLTËSNKKFL̈PFQQFGRDIĀDTTDĀVRDPQ : 580 AB263618 : YRVVVLSFELLNAPATVCGPKLSTDLIKNQCVNFNFNGLTGTGVLTPSSKRFQPFQQFGRDVSDFTDSVRDPK : 566

MN908947 : TLEILDITPCSFGGVSVITPGTN" SNQVAVLYQDVNCTEVP̄VAIHADQLTPTWRVYSTGSNVFQTRAGCLIGA : 653 AB263618 : TSEILDISPCSFGGVSVITPGTNASSSEVAVLYQDVNCTDVSTAIHADQLTPAWRIYSTGNNVFQTQAGCLIGA: 639

MN908947 : EHVNNSYECDIPIGAGICASYQTQTNSERRAR RVASQSI IAYTMSLGAENSSVAYSNNSIAIPTNFTISVTTEI : 726 AB263618 : EYVDTSYECDIPIGAGICASYHTVS....LLRSTSQKSIVAYTMSLGADSSIAYSNNTIAIPTNFSISITTEV : 708

MN908947 : LPVSMTKTSVDCTMYICGDSTECSNLLLQYGSFCTQLNRALTGIAVEQDKNTQ̄EVFAQVKQIYKTPP̄IKD̄FGG : 799 AB263618 : MPVSMÄKTSVDCNMYY ICGDSTECANLLLQYGSFCTQLNRALSGIAÄEQDRNTREVFAQVKQMYKTPTLKYFGG : 781

\section{FP}

MN908947 : FNESQILPDPSKPSKRSFIEDLLFNKVTLADAGFIKQYGDCLGDIAARDLICAQKFNGLTVLPPLLTDEMIAQ $: 872$ AB263618 : FNFSQILPDPLKPTKRSFIEDLLFNKVTLSDAGFMKQYGECLGDINARDLICAQKFNGLTVLPPLLTDDMIAÄ : 854

\section{CR}

HR1

MN908947 : YTSALLĀGTITSGWTFGAGAALQIPFAMQMAYRFNGIGVTQNVLYENQKLIANQFNSAIGKIQDSSLSSTĀSAL : 945 AB263618 : YTAALVSGTÄTÄGWTFGAGAALQI PFAMQMAYRFNGIGVTQNVLYENQKQIANQFNKAISQIQESLTTTSTAL : 927

\section{$\mathrm{CH}$}

MN908947 : GKLQDVVNQNAQALNTLVKQLSSNFGAISSVLNDILSRLDKVEAEVQIDRLITGRLQSLQTYVTQQLIRAAEI : 1018 AB263618 : GKLQDVVNQNAQALNTLVKQLSFNFGAISSVLNDILSRLDKVEAEVQIDRLITGRLQSLQTYVTQQLIRAAEI : 1000

MN908947 : RASANLAATKMSECVLGQSKRVDFCGKGYHLMSFPQSAPHGVVFLHVTYVPĀQEKN***TTAPAICHD̄̄GKAHFPR : 1091 AB263618 : RASANLAATKMSECVLGQSKRVDFCGKGYHLMSFPQAAPHGVVFLHVTYVPSQERNFTTAPAICHEGKAYFPR : 1073

MN908947 : EGVFVNGGTHWFVTQRNFYĒPQIITTDNTFVSGNCDVVIGIVNNNTVYDPLQPELDSFKEELDKYFKNHTSPDV : 1164 AB263618 : EGVFVFNGTSWFITQRNFFSPQIITTDNTFVSGNCDVVIGI INNTVYDPLQPELDSFKEELDKYFKNHTSPDV : 1146 HR2

MN908947 : DLGDISGINASAVVNIQKEIDRLNEVAKNLNESLIDLQELGKYEQYIKWPWYIWLGFIAGLIAIVMVTIMLCCM : 1237 AB263618 : DFGDISGINASVVNI QKEI DRLNEVAKNLNESLIDLQELGKYEQY I KWPWYVWLGF IAGLIAIVMVTILLCCM : 1219 


\section{Zhou et al., Figure 4}

\section{A|B}
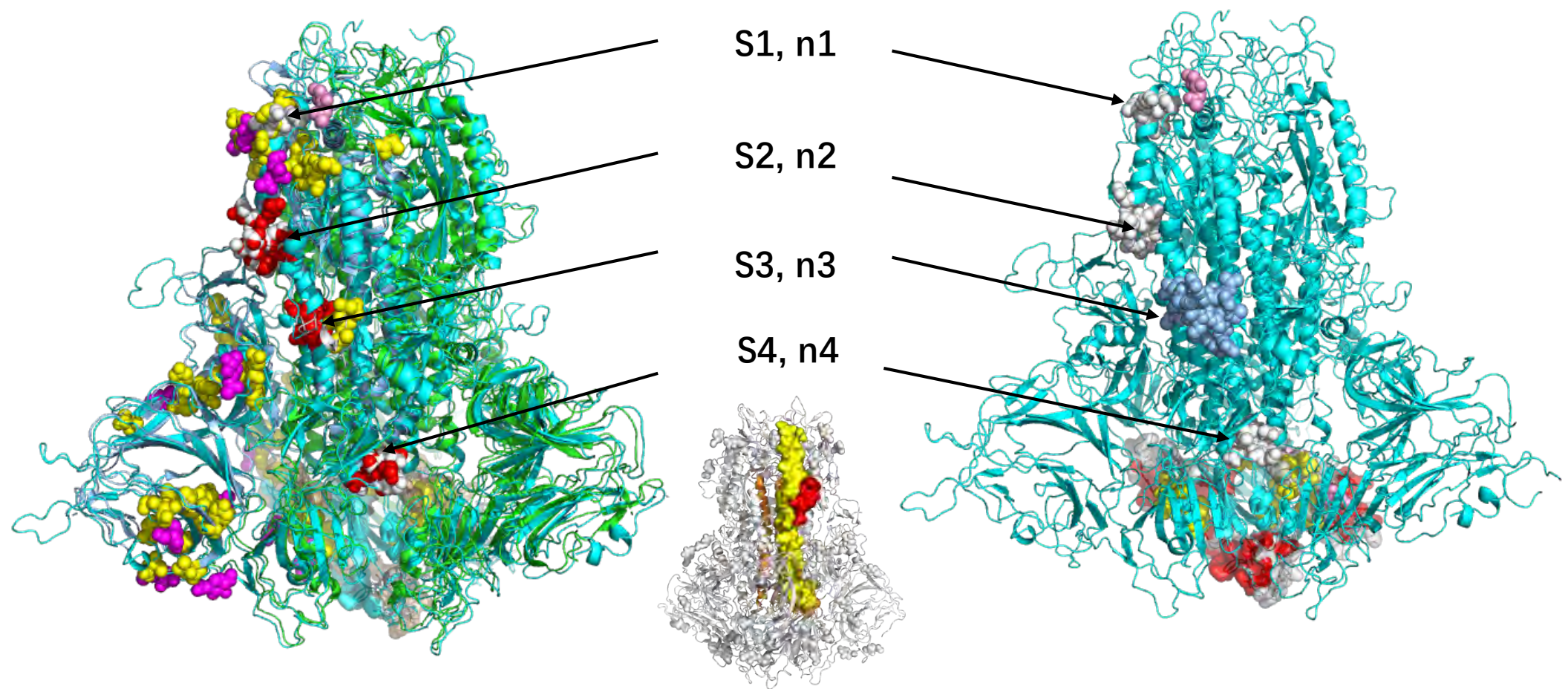
Zhou et al., Figure 4

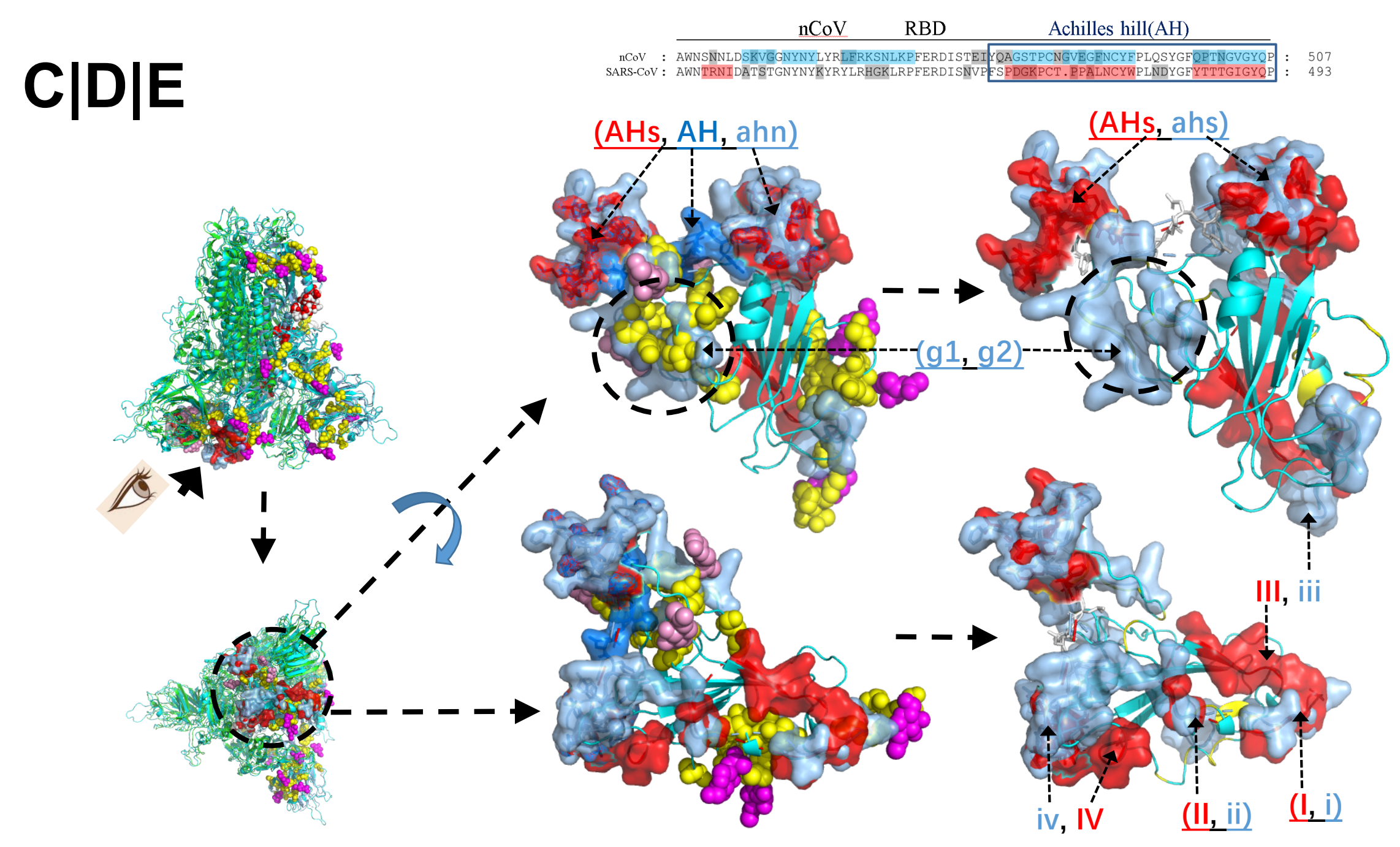


Supplemental Online Materials

Supplemental Table 1: List of monoclonal antibodies for Spike protein of SARS-CoV

Supplemental Figure 1: Scheme of Spike proteins of 2019-nCoV, SARS-CoV and MERSCoV.

Supplemental Figure 2: Structure-based alignment of 2019-nCoV and SARS-CoV Spike proteins. The sequences are directly extracted from PDB 5X58 and 2019-nCoV homology model, and the sequence alignment was based on above two structures by ENDscript and ESPRIPT with default settings ( http://espript.ibcp.fr/ESPript/ENDscript/index.php ).

Supplemental Figure 3: Accessible surface area profiling of Spike proteins of 2019-nCoV and SARS-CoV. A) The epitopes predicted on the S protein structure for SARS-CoV, Epi (yellow) denotes the epitopes screened by simple ASA profiling (the same for nCoV), and EpiS (red) denotes the epitopes were calculated by excluding the glycosylation sites and the glycointeracting amino acids; B) The epitopes predicted for $\mathrm{nCoV}$. The values of $\mathrm{Y}$ axis means $\mathrm{nm}^{2}$ of ASA.

Supplemental Figure 4: Connecting region (CR) of 2019-nCoV and SARS-CoV Spike proteins.

Supplemental Figure 5: Furin recognition site of 2019-nCoV Spike protein. 
Supplemental Table 1: List of monoclonal antibodies for Spike protein of SARS-CoV

\begin{tabular}{|c|c|c|c|}
\hline Antibody binding site & Nearby N-glycosylation & Clone & Ref \\
\hline \multicolumn{4}{|l|}{ N-terminal domain (NBD) } \\
\hline 130 FELCDNPFFAVSKPMGTQTHT 150 & $158 \mathrm{NCT}$ & 68 & 3 \\
\hline 236 TAFSPAQDIWGTSAAAYF 253 & 227 NIT & $\begin{array}{l}\text { 114E3,115H2,116F } 8,11 \\
\text { 2F9,120D9 }\end{array}$ & 14 \\
\hline \multicolumn{4}{|l|}{ Receptor binding domain (RBD) } \\
\hline W423,N424 & & S-9-11,N-176-15 & 7 \\
\hline 435 NYNYKYRYLRHGKLRPF 451 & & 4D5 & \multirow{2}{*}{8} \\
\hline 442 YLRHGKLRPFERDISNVPFSPDGK 465 & & $17 \mathrm{H} 9$ & \\
\hline 460 FSPDGKPCTPPALNCYW 476 & & F26G18 & \multirow[b]{2}{*}{9} \\
\hline Unknown sites in SARS RBD & & $\begin{array}{l}\text { F26G9,F26G10,F26G1 } \\
9\end{array}$ & \\
\hline F360,Y442, L472, D480, T487 & 357NST & CR3006 & \multirow{2}{*}{10} \\
\hline Unknown sites in SARS RBD & & CR3013 CR3014 & \\
\hline L472,N479,D480 & & $80 \mathrm{R}$ & \multirow{3}{*}{11} \\
\hline N479 & & CS5、CS84、FM6 & \\
\hline R395, R426, F483, Y484,I489, Y491, Q492 & & m396 & \\
\hline $\mathrm{T} 332, \mathrm{~N} 479, \mathrm{D} 463$ & 330NAT & FM39 & 12 \\
\hline P462,N479 & & CR3014 & \multirow{2}{*}{13} \\
\hline Unknown sites outside of SARS RBD & & CR3022 & \\
\hline $\begin{array}{l}\text { T359,G391,D392,N424,R426,N427,T486,488 } \\
\text { GIGYQ 492 }\end{array}$ & $357 \mathrm{NST}$ & F26G19 & 16 \\
\hline $\begin{array}{l}\text { T359,T363,K365,390 KGD } \\
\text { 392,V394,R395,R426,S432, } \\
\text { Y436,G482,484 YTTTGIGYQ } 492 \\
\end{array}$ & $357 \mathrm{NST}$ & m396 & 17 \\
\hline \multicolumn{3}{|l|}{ R426,S432,T433,Y436,N437,K439, Y440,Y442, } & \multirow[b]{2}{*}{18} \\
\hline $\begin{array}{l}470 \text { PALNCYWPLND 480,484 YTTTGI 489, } \\
\text { Y491,Q492 }\end{array}$ & & $80 \mathrm{R}$ & \\
\hline 490 GYQPYRVVVLSFELLNAPATV 510 & & 201 & 3 \\
\hline \multicolumn{4}{|l|}{$\mathrm{S} 1$ (non-RBD) and S2 subunits } \\
\hline 536 GVLTPSSKRFQPFQQFG 552 & & $114 \mathrm{G} 5$ & 14 \\
\hline 612 ADQLTPAWR 620 & $602 \mathrm{NCT}$ & F26G8 & 9 \\
\hline 549 QQFGRDVSDF 558 & & $\begin{array}{l}\text { 101F10,103F2,104D4,1 } \\
11 \mathrm{~A} 7,121 \mathrm{~B} 8\end{array}$ & 14 \\
\hline 731 CANLLLQYGSFCTQL 745 & & $65 \mathrm{~B} 3,63 \mathrm{~B} 10$ & 6 \\
\hline 791 PLKPTKRSFIEDLLF 805 & 783NFS & $5 \mathrm{H} 10^{*}$ & 6 \\
\hline 814 GFMKQYGECL 823 & & $102 \mathrm{D} 7$ & 14 \\
\hline 1125 PELDSFKEELDKYFKNH 1141 & $1116 \mathrm{NNT}$ & $119 \mathrm{~F} 6$ & 14 \\
\hline
\end{tabular}

*Generated by immunizing mice with recombinant Spike protein produced in Escherichia coli. 
2019-nCoV

Zhou et al., Figure S1

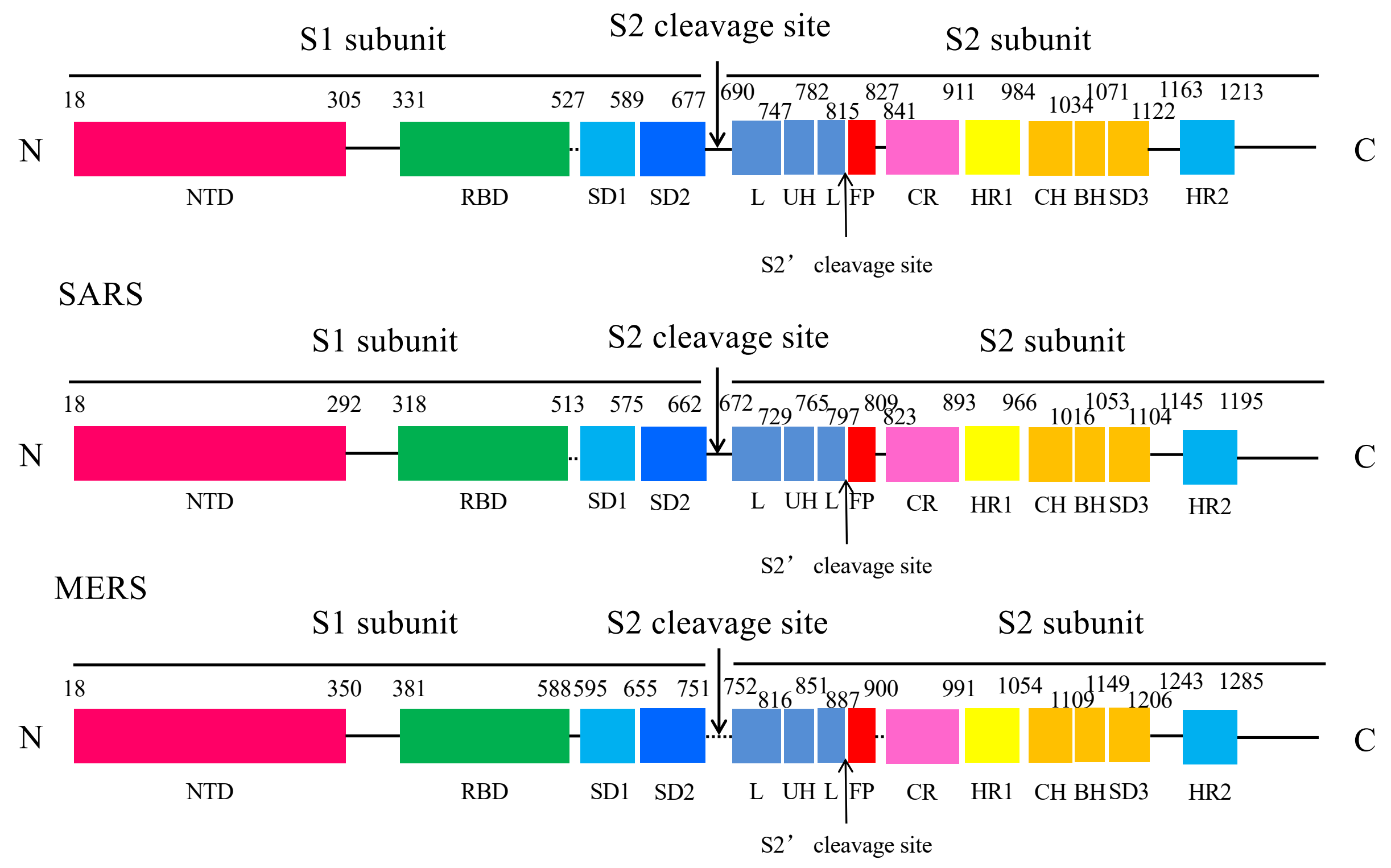




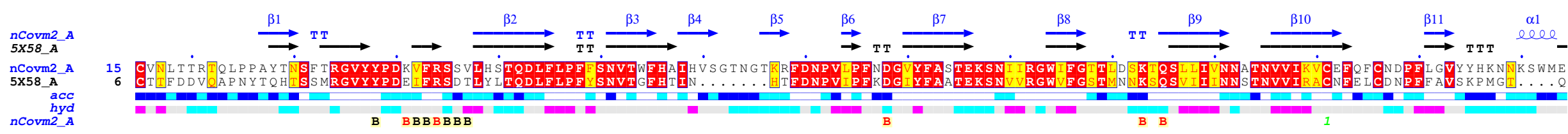

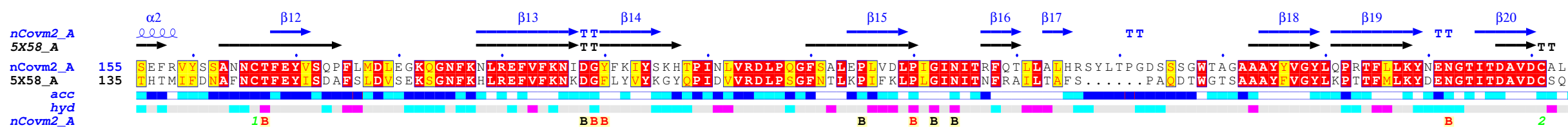

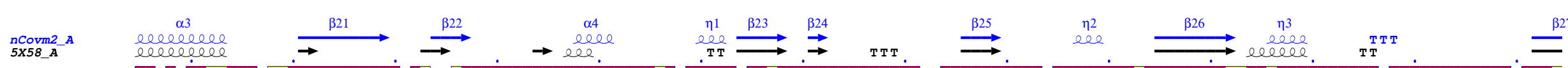

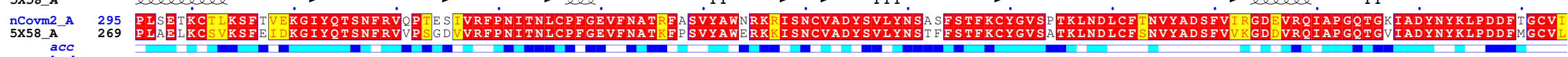

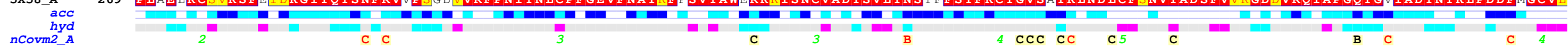

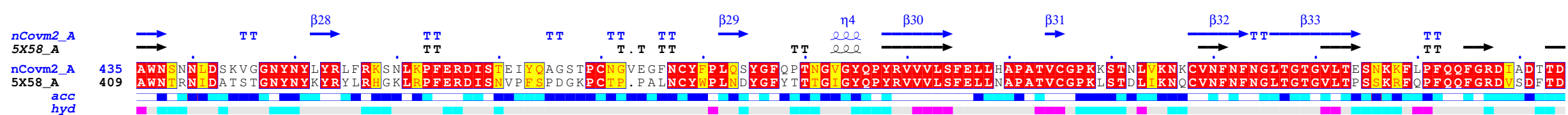

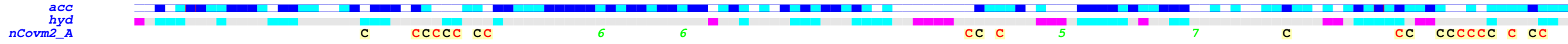

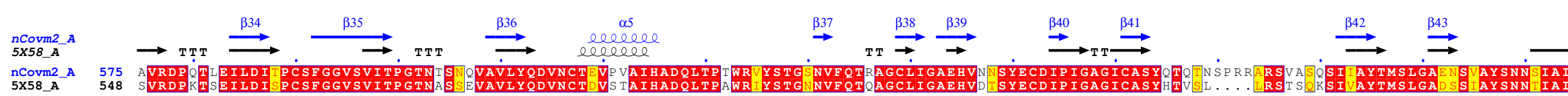

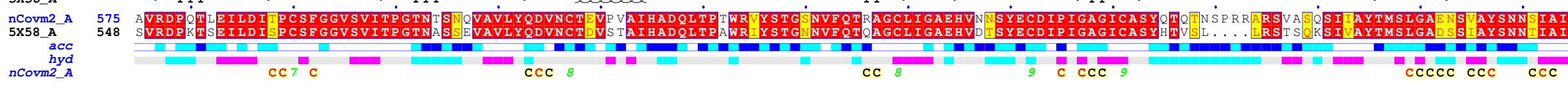

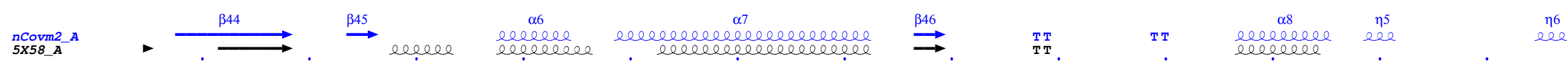

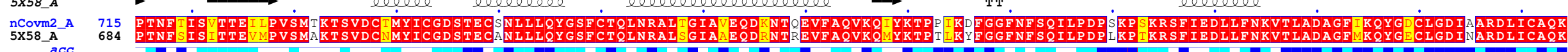

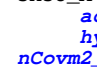

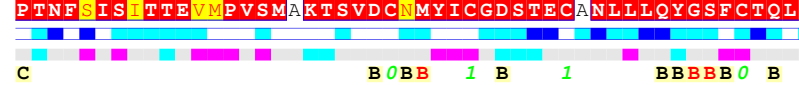

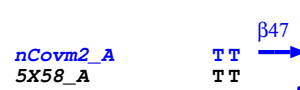

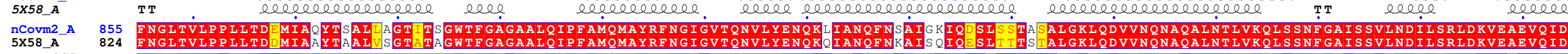
${ }_{\mathrm{B}} \mathrm{B} \mathrm{BB}_{\mathrm{B}}$

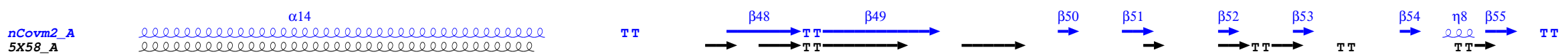

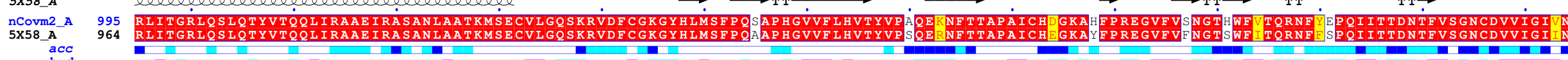

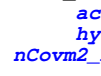

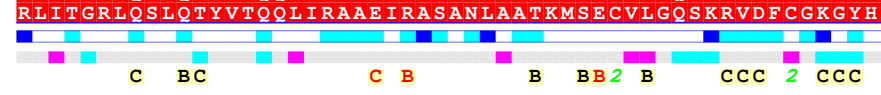

$\underset{5 \times 58 \_-A}{n C o v m 2 A}$

$\begin{array}{ccc}\text { nCovm2 } 2 \mathrm{~A} & 1135 \\ 5 \times 58-\mathrm{A} & \mathbf{N T V} \\ \text { acc } \\ \text { acd } \\ h y d\end{array}$ 


\section{Zhou et al., Figure S3}

\section{SARS RBD}

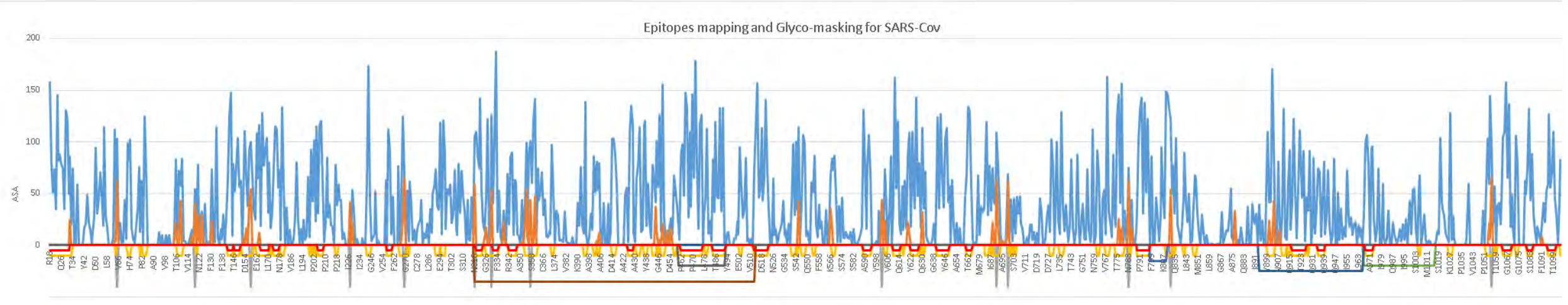

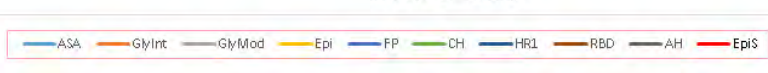

\section{9-nCoV}

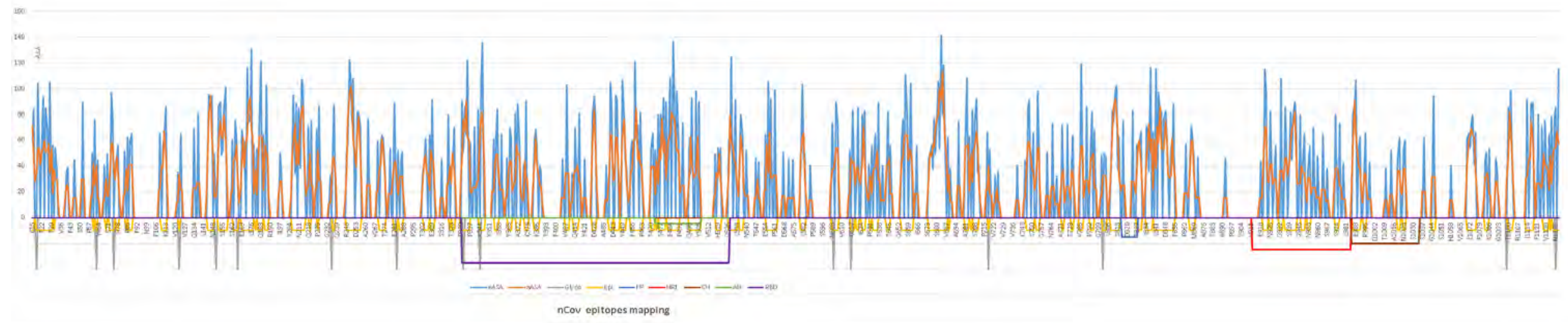


Zhou et al., Figure S4

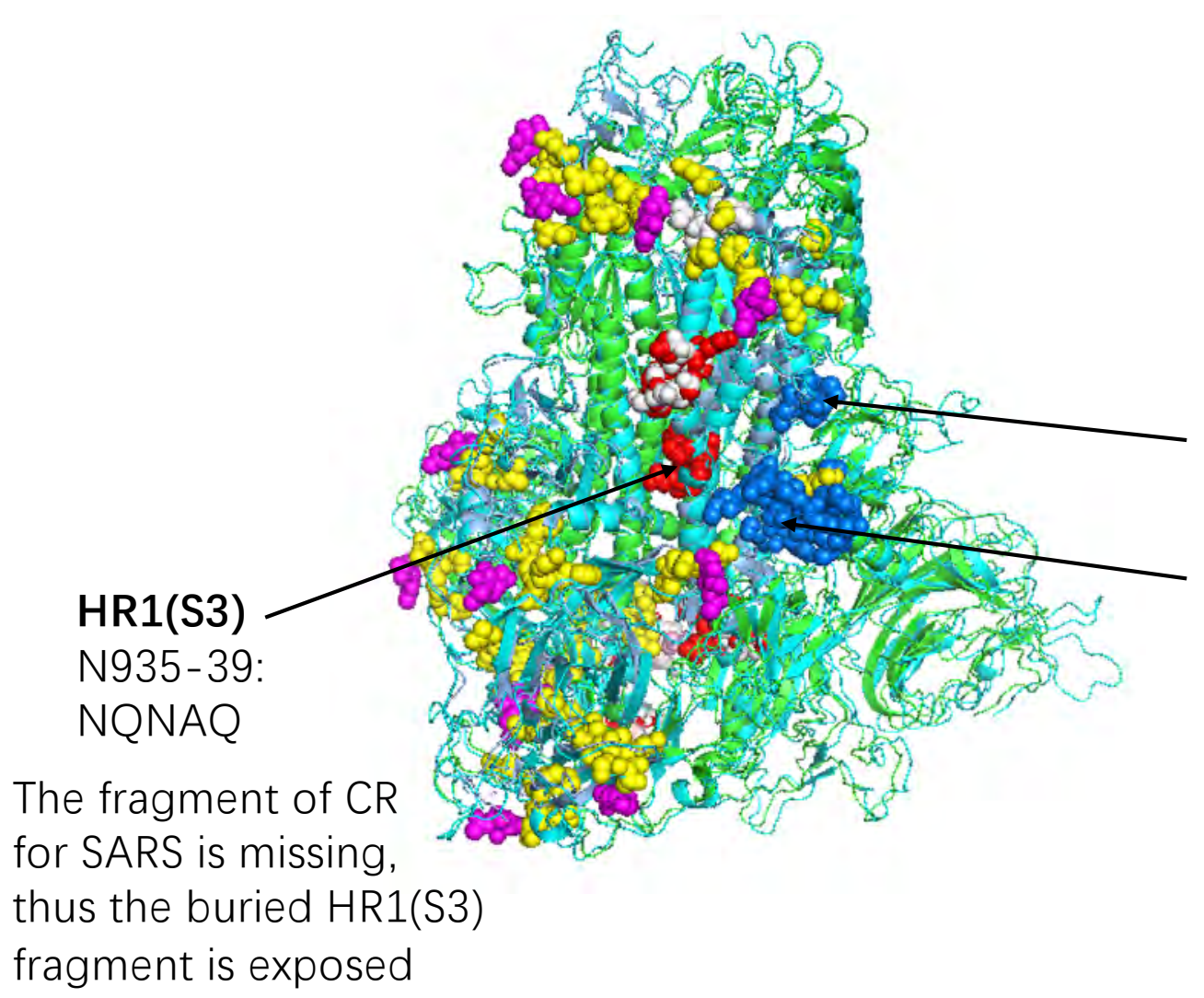

CR nCoV(close epitope)

T866-69:

TDEM

CR nCoV(n3)

I834-54:

IKQYGCLGDIAARDLICAQK

$\mathrm{CR}(\mathrm{n} 3)$ is exposed, and located exactly outside of S3

fragment is exposed 


\section{Zhou et al., Figure S5}

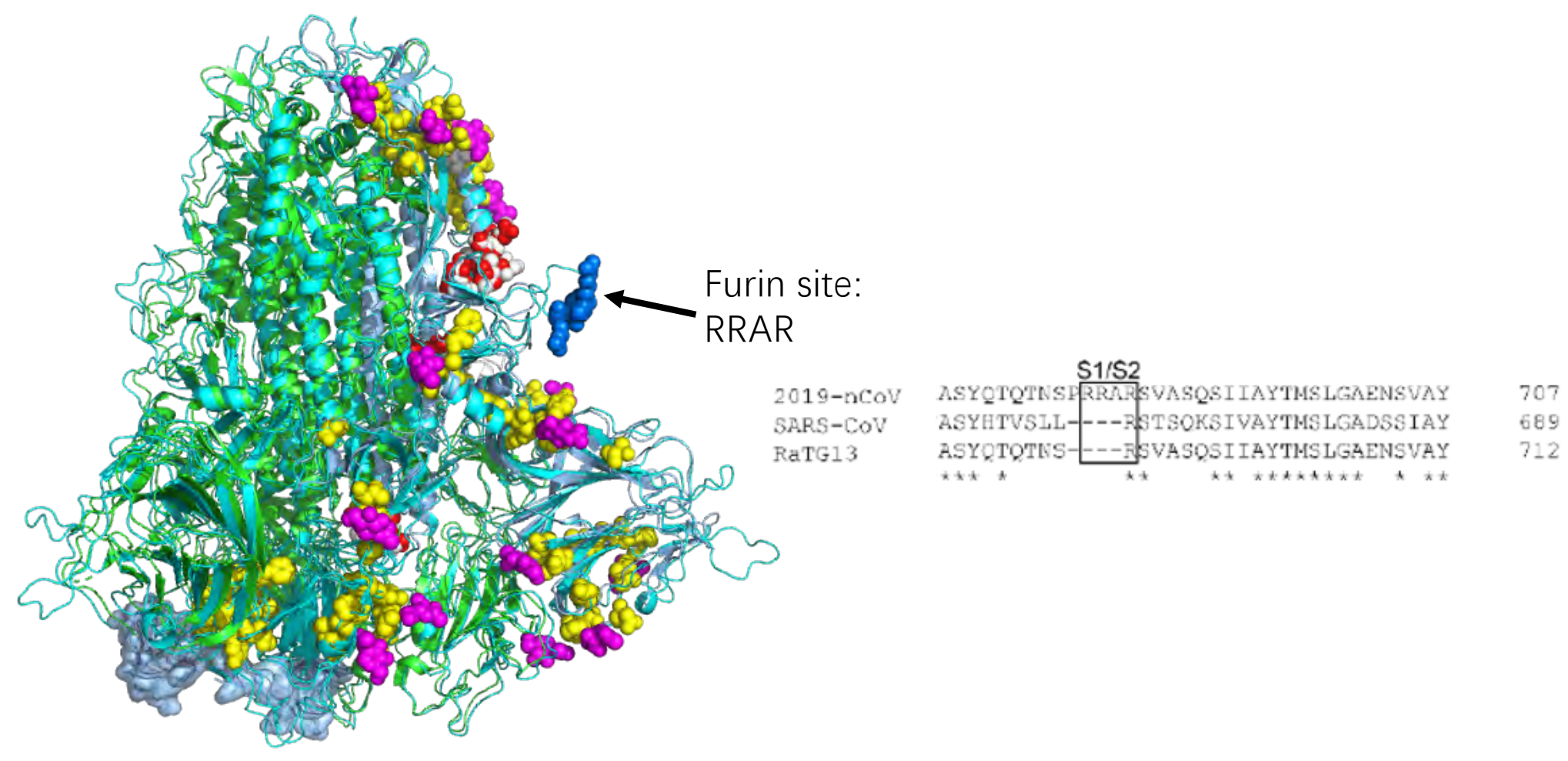

